\title{
When enemies do not become friends: Experimental evolution of heat-stress adaptation in a vertically transmitted parasite
}

Eike Dusi1,2, Sascha Krenek1,3, Thomas Petzoldt1, Oliver Kaltz2* and Thomas U. Berendonk1

1Institute of Hydrobiology, Technische Universität Dresden, Germany

2ISEM, Université de Montpellier, CNRS, IRD, EPHE, Montpellier, France

3Department of River Ecology, Helmholtz Centre for Environmental Research - UFZ,

Magdeburg, Germany

10

*Author for correspondence: oliver.kaltz@umontpellier.fr

Author contributions: ED, SK and TUB conceived the study; ED conducted the experiment.

OK, ED and TP conducted the statistical analyses. OK and ED wrote the manuscript; SK, TP and TUB provided comments on the manuscript. All authors gave final approval for submission.

Short title: Symbiont heat stress adaptation 
Abstract. Strict vertical (parent-to-offspring) transmission of symbionts may be associated with benevolence and mutualism, because host reproduction and symbiont transmission are linked. Nonetheless, many such symbionts do reduce host fitness costs and the factors driving their evolution are unclear. Using microcosm populations of Caedibacter taeniospiralis, a vertically transmitted bacterial symbiont of the protozoan Paramecium tetraurelia, we investigated evolutionary change under permissive conditions $\left(26^{\circ} \mathrm{C}\right)$ and under heat stress $\left(32^{\circ} \mathrm{C}\right)$, over 150 host generations. We found evidence for symbiont adaptation to heat stress, involving increased infection persistence and, consequently, higher rates of vertical transmission. For certain genetic backgrounds, heat-stress adaptation was associated with higher proliferation of infected lines at $26^{\circ} \mathrm{C}$, suggesting cost-free evolution of supergeneralists. Despite a general decrease in symbiont virulence relative to ancestral strains, infected evolved lines still showed substantial reductions $(>20 \%)$ in population growth. There was no sign of a temperature-specific reduction in virulence or protection of the host against heat stress. Our results show that obligately vertically transmitted symbionts can still qualify as 'parasites' and evolve adaptations that do not help their hosts. Long-term infection persistence might require additional mechanisms, such as the symbiont-mediated 'killer trait' in this system, allowing the selective elimination of uninfected individuals in the population.

40 Keywords: costs of adaptation, Paramecium, parasite, specialist-generalist, temperature, virulence 
bioRxiv preprint doi: https://doi.org/10.1101/2020.01.23.917773; this version posted January 24,2020 . The copyright holder for this preprint (which was not certified by peer review) is the author/funder, who has granted bioRxiv a license to display the preprint in perpetuity. It is made available under aCC-BY-NC-ND 4.0 International license.

\section{Introduction}

45 Symbiosis generally involves transfer of resources and services between the two interacting species, thereby generating reciprocal impacts on their fitness (Thrall et al. 2007; Leung and Poulin 2008). The outcome of an interaction, from positive (mutualism) to neutral (commensalism) to negative/antagonistic (parasitism), depends on the net effect of costs and benefits for the players involved. Over the past years, an increasing number of studies have suggested that this balance between costs and benefits is strongly condition-dependent, with systems potentially shifting back and forth on a mutualism-parasitism continuum (Michalakis et al. 1992; Brown 2003; Restif and Kaltz 2006; Thompson and Fernandez 2006; Wolinska and King 2009; Vale et al. 2011). Factors determining sign and strength of an interaction are the symbiont transmission mode, environmental conditions, as well as the genetic background of symbiont and host (Ewald 1987; Wolinska and King 2009). Most empirical and experimental work has highlighted the short-term consequences of variation in these factors over one or very few generations (Thomas and Blanford 2003; Wolinska and King 2009; Ebert 2013), but it is still less clear how they drive long-term evolutionary and coevolutionary processes (Mahmud et al. 2017; Shapiro and Turner 2018; Hatcher et al. 2005). Symbionts with exclusive vertical transmission are particularly interesting in this context. Vertical transmission occurs from infected parents to offspring, and therefore symbiont transmission success is directly linked with host reproduction (Fine 1975). Unlike in systems with infectious horizontal transmission, allowing some degree of host exploitation and damage (Alizon et al. 2009), symbiont and host fitness are positively aligned, so that vertically transmitted symbionts should evolve to avoid harm to their host or even become beneficial (Ewald 1987; Jones et al. 2007; Ebert 2013). Moreover, under exclusive vertical transmission, the symbiont is locked up in a single line of descendant. This may lead to the accumulation of deleterious mutations or loss of function (Dale and Moran 2006; Feldhaar 
2011), but also facilitate specialisation and co-evolution (Brucker and Bordenstein 2012;

Jaenike 2015). These ideas are consistent with the observation that some of the major evolutionary transitions from parasitic to mutualistic relationships are associated with a switch from horizontal to vertical transmission, as shown across the phylogenetic tree (Moran et al. 2008; Sachs et al. 2011), but also in microcosm experiments (e.g., Dusi et al. 2015; Shapiro and Turner 2018).

Nonetheless, many vertically transmitted symbionts are known to be harmful to their host, qualifying them as parasites (Kelly et al. 2003; Mouton et al. 2004; Ebert 2013; Dusi et al. 2014). In some cases, this can be explained by the existence of residual horizontal transmission, offsetting the negative effects on host fitness. In other cases, symbionts manipulate host's reproductive system in such a way that uninfected individuals are eliminated from the population (e.g., cytoplasmic incompatibility or male killing in Wolbachia, thereby increasing the frequency of the symbiont in the population despite its actual fitness costs (Werren 1997; Dunn and Smith 2001; Dunn et al. 2001). Alternatively, vertically transmitted symbionts may provide benefits against natural enemies (Oliver et al. 2005; Haine 2008; Brownlie and Johnson 2009; Jones et al. 2011), competitors or adverse environmental conditions, such as pollutants or high-temperature stress (Russell and Moran 2006; Douglas 1998). Such condition-dependent benefits may open the evolutionary avenue towards mutualism (Fellous and Salvaudon 2009).

We still know very little about how environmental variation impacts the evolutionary dynamics of systems with obligate vertical transmission. For example, in Buchnera, a bacterial symbiont of aphids, a single point mutation in the symbiont genome seems to drive a balanced polymorphism of wild-type strains that confer heat-stress protection, but impose fitness costs at lower temperature, and non-protecting mutants that bear no fitness costs at lower temperatures (Dunbar et al. 2007). Variation in heat-stress protection also exists among genotypes (or species) of other aphid-symbionts, indicating a genetic basis on which selection 
can act (Russell and Moran 2006; Cayetano and Vorburger 2013). Similarly, genetic variation in temperature sensitivity is known for within-host density of Wolbachia spp., a widely distributed bacterial symbiont of arthropods (Mouton et al. 2003), although it is less clear how this effect impacts host fitness and thus potential responses to selection (Mouton et al. 2007).

Typically, the above-mentioned experimental work on temperature effects is based on 100 single host individuals and their offspring, spanning little more than one host generation and thereby limiting information on selective, population-wide processes (but see Rouchet and Vorburger 2014). In the present study, we investigated how heat stress conditions affect evolution in experimental microcosm populations of the freshwater protozoan Paramecium tetraurelia, infected with the strictly vertically transmitted bacterium Caedibacter

105 taeniospiralis. Vertical transmission occurs through the segregation of bacterial cells into the daughter cells of the asexually dividing host. Infection with the symbiont reduces host fitness (Dusi et al. 2014; but see Grosser et al. 2018), but it also confers a so-called 'killer trait' to the host, leading to the selective killing of uninfected conspecifics in the population (Sonneborn 1943; Schrallhammer and Schweikert 2009). This effect is similar to the male-killing or cytoplasmatic incompatibility of Wolbachia or Cardinium, which also promotes an increase in the frequency of symbiont carriers in the population by eliminating non-carriers (Hurst et al. 2000; Gotoh et al. 2007).

In a long-term experiment, we exposed infected populations with 5 different genotype associations to a $32^{\circ} \mathrm{C}$ high-temperature treatment and to a $26^{\circ} \mathrm{C}$ control treatment. In a

115 previous short-term experiment, infection prevalence had declined at $32^{\circ} \mathrm{C}$, indicating limited heat tolerance of the symbiont (Dusi et al. 2014). Thus, the first objective of this study was to test whether this system can evolve in such a way that infection is maintained at the stressful temperature $\left(32^{\circ} \mathrm{C}\right)$. Moreover, Grosser et al (2018) demonstrated that Caedibacter infection is associated with increased expression of Heat Shock Protein (HSP70), a protective agent against temperature stress (Sorensen et al. 2003). Our second objective was therefore to test 
bioRxiv preprint doi: https://doi.org/10.1101/2020.01.23.917773; this version posted January 24,2020 . The copyright holder for this preprint (which was not certified by peer review) is the author/funder, who has granted bioRxiv a license to display the preprint in perpetuity. It is made available under aCC-BY-NC-ND 4.0 International license.

whether adaptation to high temperature involved the evolution of reduced virulence or even beneficial effects of infection on its host. After ca. 150 host generations, we performed adaptation assays, comparing ancestral and evolved host-symbiont lines for their capacity to maintain infection and their growth performance. Lines were assayed at both temperatures $125\left(26^{\circ} \mathrm{C}\right.$ and $\left.32^{\circ} \mathrm{C}\right)$ to test whether adaptation to the high-temperature environment traded off with the performance at the original permissive temperature.

\section{Methods}

\section{STUDY SYSTEM}

130 The gammaproteobacterium Caedibacter taeniospiralis (Preer and Preer 1982) occupies the cytoplasm of its host Paramecium tetraurelia, a cosmopolitan fresh-water ciliate (Ciliophora). Transmission occurs vertically during mitotic host cell division, from the infected mother cell to the two resulting daughter cells. Free-living stages or horizontal transmission are unknown; quasi-horizontal transmission during sexual conjugation is theoretically possible, but has to

135 our knowledge never been documented. Infection reduces host fitness (Dusi et al. 2014), but the parasite also confers a so-called 'killer trait' to the host, leading to the selective elimination of uninfected Paramecium in the population (Schrallhammer and Schweikert 2009). Infection prevalence is stably maintained at temperatures $\leq 26^{\circ} \mathrm{C}$, but rapidly declines at $32^{\circ} \mathrm{C}$ (Dusi et al. 2014). Thus high temperature cures Paramecium from infection; it also suggests that the

140 killer-trait is inefficient at this temperature, as cured cells would otherwise be killed by infected cells (Grosser et al. 2018).

\section{LONG-TERM SELECTION EXPERIMENT}

The long-term selection experiment employed five Paramecium tetraurelia strains, each

145 associated with its own Caedibacter taeniospiralis symbiont (Preer et al. 1974). Stock 
bioRxiv preprint doi: https://doi.org/10.1101/2020.01.23.917773; this version posted January 24,2020 . The copyright holder for this preprint (which was not certified by peer review) is the author/funder, who has granted bioRxiv a license to display the preprint in perpetuity. It is made available under aCC-BY-NC-ND 4.0 International license.

cultures of these strains are maintained in $0.25 \%$ Cerophyl medium (Krenek et al. 2011), inoculated with Raoultella planticola (DMSZ 3069) at $22^{\circ} \mathrm{C}$.

Following the results from Dusi et al. (2014), we established a stressful hightemperature selection treatment at $32^{\circ} \mathrm{C}$, and a permissive control treatment at $26^{\circ} \mathrm{C}$, close to 150 the optimum for Paramecium growth and allowing stable persistence of Caedibacter. For each strain, three long-term replicate populations (referred to as 'selection line', hereafter) were assigned to each selection temperature, giving a total of 30 populations ( 5 host strains $\mathrm{x}$ 3 replicates x 2 selection temperatures; Fig. S1). Selection lines had an initial host cell density of 500 cells $\mathrm{ml}-1$ in $40 \mathrm{ml}$ of culture medium ( $60 \mathrm{ml}$ flasks); initial infection prevalence (i.e.,

155 the proportion of infected hosts) was $100 \%$. The selection lines were kept in computercontrolled water baths (for details, see Dusi et al. 2014). Several water baths were assigned to each of the two treatment temperatures, and cultures randomly assigned to a given water bath. Over the course of the experiment, we regularly changed the position of the cultures within and between water baths of the same temperature. Every 2-3 days, $20 \mathrm{ml}$ of culture were

160 replaced with freshly bacterized medium. This ensured regular periods of population growth, with approximately three host generations per week. We measured host density and infection prevalence in 2-month intervals (approximately every 25 host generations), as described in Dusi et al. (2014). Note that prevalence data for individual selection lines are only available for the second half of the experiment.

Ancestral cultures were maintained at $10^{\circ} \mathrm{C}$, with $25 \%$ of the population replaced with freshly bacterized medium every three weeks. This protocol minimised cell division $(\approx 1$ complete population turnover in 12 weeks) over the 52 weeks of the long-term experiment.

\section{ADAPTATION ASSAY}

170 After 52 weeks (ca. 150 host generations), we performed an adaptation assay (Fig. S1). Three single Paramecium cells were isolated from each selection line, washed in sterile Dryl's 
175 long-term experiment and re-acclimatised for 8 days at $22^{\circ} \mathrm{C}$ prior to use. Next, each monoclonal line was split and one half was cured from infection by adding the antibiotic streptomycin (Krenek et al. 2012; Dusi et al. 2014). The presence of infection and its absence after antibiotic treatment was verified using FISH and PCR techniques (Dusi et al. 2014).

Infected and cured monoclonal lines were tested at both $26^{\circ} \mathrm{C}$ and $32^{\circ} \mathrm{C}$. To this end, 180 each monoclonal line was further split into two pre-cultures (Fig. S1). One remained at its original selection temperature; the other was acclimatised in steps of $+/-2^{\circ} \mathrm{C}$ per day to the 'foreign' assay temperature and remained at this temperature for another two days prior to the assay. In the same way, ancestral monoclonal cultures were acclimatised to the two temperatures.

From the acclimatised pre-cultures, we started individual assay replicates in flasks containing $20 \mathrm{ml}$ of culture medium, at initial densities of ca. 25 cells $\mathrm{ml}-1$ and $100 \%$ infection or $0 \%$ infection (cured replicates). The flasks were placed in water baths at assay temperatures of $26^{\circ} \mathrm{C}$ or $32^{\circ} \mathrm{C}$. Density was estimated from cell counts in $25-300 \mu l$ samples under a dissecting microscope, taken in 6-10h intervals, for a total of $80 \mathrm{~h}$. Using FISH, we determined 190 the proportion of infected cells after c. 48h, when populations were reaching carrying capacity.

Due to very low levels of infection or even entire loss of infection in the $32^{\circ} \mathrm{C}$ longterm selection treatment (see Results), all selection lines from strain 47 and one from strain 51 were omitted from the assay. Thus, in total, we assayed 23 selection lines and the four ancestral strains, with a total of 324 replicates (27 populations x 3 monoclonal lines x 2 infection status (infected / cured) x 2 assay temperatures). 


\section{STATISTICAL ANALYSIS}

We analysed variation in three parameters:

200 (1) Infection persistence, i.e., the proportion of infected individuals in an (infected) assay replicate after $48 \mathrm{~h}$. This measure is related to the fidelity of vertical transmission during periods of host population growth as well as to the resistance of the parasite to the high temperature exposure $\left(32^{\circ} \mathrm{C}\right)$.

(2) Virulence, taken as the difference in growth between infected and cured assay replicates.

205 Infection influenced both growth rate (r) and carrying capacity (K) (Fig. S2). To obtain a combined measure, we calculated the Area Under the Curve (AUC) of density for each assay replicate after 56h, using the trapezoidal method. The AUC represents the cumulative density during the assay, weighted for the time interval between measurements (Capaul and Ebert 2003; Adiba et al. 2010). The AUC is convenient, because it summarises growth in a single value per replicate. We calculated the AUC over the first $56 \mathrm{~h}$ to remain close to the estimates of infection prevalence $(\approx 48 \mathrm{~h})$, but nonetheless integrate values close to carrying capacity (correlation between AUC56h and AUC80h: r =0.96, $\mathrm{n}=324, \mathrm{p}<0.0001$ ). For each combination of monoclonal line and assay temperature, there was one infected and one cured assay replicate, and virulence was calculated as the difference between them: [(AUCinfected) /

215 (AUC cured $_{\text {) }}$ - 1. Thus, negative values indicate a negative effect of infection on host population growth. We did not specifically correct these estimates for loss of infection at $32^{\circ} \mathrm{C}$ assay temperature. There was no significant relationship between assay infection prevalence after $48 \mathrm{~h}$ and virulence $(\mathrm{r}=0.07, \mathrm{n}=81, \mathrm{p}>0.5)$, and adding prevalence as a covariate produced no significant changes in the main analysis of virulence (main effect of

220 prevalence, interactions with other terms in the model: all $p>0.3$ ).

(3) Vertical transmission rate, calculated as: [(infection prevalence) $48 \mathrm{~h} \mathrm{X}$ (density)48h (density)oh] / [(density)0h X 48h]. Integrating over host reproductive rate and the fidelity of vertical transmission, this measure describes the proliferation of infected cells and therefore 
bioRxiv preprint doi: https://doi.org/10.1101/2020.01.23.917773; this version posted January 24,2020 . The copyright holder for this preprint (which was not certified by peer review) is the author/funder, who has granted bioRxiv a license to display the preprint in perpetuity. It is made available under aCC-BY-NC-ND 4.0 International license.

represents an estimate of the vertical transmission rate $\left(\mathrm{R}_{0}\right)$ of Caedibacter (Mangin et al. 1995).

Using General Linear Models (GLM), we analysed variation in infection prevalence with a binomial error structure (logit link), and variation in virulence and in (square-roottransformed) vertical transmission rate with a normal error structure. We fitted fully factorial models with selection temperature (long-term $26^{\circ} \mathrm{C}, 32^{\circ} \mathrm{C}$ or ancestor), assay temperature $\left(26^{\circ} \mathrm{C}\right.$ or $\left.32^{\circ} \mathrm{C}\right)$ and strain genetic background $(\mathrm{A} 30,116,51,298)$ as model terms. Selection line and monoclonal line identity were included as nested terms and considered as random factors for hypothesis testing. Post-hoc contrasts compared selection treatments separately for each assay temperature and strain background.

We performed two analyses of trait relationships. First, we performed multiple 235 regressions to test how changes in vertical transmission rate (response variable) depended on change in infection persistence and/or change in virulence (explanatory variables). Trait change was calculated as the difference between the value of each evolved line and the mean of the corresponding ancestral strain. All selection lines were pooled and analyses performed for $26^{\circ} \mathrm{C}$ and $32^{\circ} \mathrm{C}$ assay temperatures, respectively. Second, in a Covariance Analysis (Bell

240 1989; He et al. 2009; Pariaud et al. 2013), we tested whether experimental long-term treatments affected the covariance between vertical transmission rates at $26^{\circ} \mathrm{C}$ and at $32^{\circ} \mathrm{C}$. This analysis considers data at 26 and $32^{\circ} \mathrm{C}$ as joint response variables. For example, a negative covariance would be indicative of a trade-off. Analogous to variance partitioning in univariate ANOVA, it allows covariance partitioning in multifactorial models (for details, see

245 Bell 1989). In our case, model terms were long-term treatment, strain genetic background and selection line identity. Analyses were performed with JMP (SAS Institute 2017). 


\section{Results}

\section{DEMOGRAPHY AND EPIDEMIOLOGY DURING THE LONG-TERM SELECTION}

\section{EXPERIMENT}

Over the 52 weeks of the experiment, we observed a negative effect of high-temperature stress on Paramecium cell density (Fig. 1a). While density at $26^{\circ} \mathrm{C}$ reached levels of over 4000 cells per $\mathrm{ml}$, it rarely exceeded $1000-2000$ cells per $\mathrm{ml}$ at $32^{\circ} \mathrm{C}$. Furthermore, infection remained at nearly $100 \%$ in the $26^{\circ} \mathrm{C}$ control lines, but generally declined at $32^{\circ} \mathrm{C}$, with four

255 selection lines (all from strain 47 and one from strain 51) even losing infection completely (Fig. 1b). Only for one strain (298), infection remained at nearly $100 \%$ at $32^{\circ} \mathrm{C}$.

\section{ADAPTATION ASSAY}

Responses to selection

260 Infection persistence. Because the fit for the full statistical model did not converge (due to nearly no variation at $26^{\circ} \mathrm{C}$ assay temperature), we run models separately for each assay temperature (Table S1). At $26^{\circ} \mathrm{C}$ assay temperature, infection prevalence remained at $100 \%$ in more than $90 \%$ of the replicates (mean proportion infection: $0.99 \pm 0.003$ ), and the analysis did not detect any significant effects of genetic background or selection treatment (Fig. 2a,

265 Table S1). In contrast, infection prevalence generally decreased over the $48 \mathrm{~h}$ at $32^{\circ} \mathrm{C}$ (Fig. $2 b)$. This decrease varied significantly with strain identity $\left(F_{3}, 15=10.47, p=0.0006\right)$ and with selection treatment origin $\left(F_{2}, 15=12.53, p=0.0006\right.$; Table $\left.\mathrm{S} 1\right)$. Namely, prevalence was less reduced in lines from the $32^{\circ} \mathrm{C}$ selection treatment $(-20 \%$ or less prevalence reduction) than in ancestral lines or lines from the $26^{\circ} \mathrm{C}$ selection treatment (up to $-60 \%$ reduction; Fig. $2 \mathrm{~b}$ ), indicating a general positive direct response to selection for infection persistence at this temperature. 
Virulence. We found substantial levels of virulence for all selection lines (Fig. 2c, d). On average, infected lines produced $40 \%$ lower densities than their cured, symbiont-free counterparts $\left(\mathrm{t}_{23}=19.9, \mathrm{p}<0.0001\right)$. There was an overall trend of evolution towards lower

275 virulence (mean difference evolved vs ancestral lines: $\mathrm{t}_{22}=4.25, \mathrm{p}=0.0002$ ). This virulence reduction in evolved lines tended to be expressed more clearly when lines were measured at $32^{\circ} \mathrm{C}$ (assay temperature $\mathrm{x}$ selection temperature: $\mathrm{F}_{2,15}=4.96, \mathrm{p}=0.0222$; Table S2; Fig. $2 \mathrm{~d}$ ). Unlike for infection persistence, there was little evidence for specific adaptation to the longterm temperature treatments. Instead, detailed analysis revealed highly variable patterns for different strain genetic backgrounds (assay temperature $\mathrm{x}$ selection temperature $\mathrm{x}$ strain background: $F 6,15=10.8, p=0.0001$; Table S2). Thus, in only two cases, 'local' selection lines were less virulent than foreign lines (strain 298 evolved at $26^{\circ} \mathrm{C}$, Fig. 2 c; strain 116 evolved at $32^{\circ} \mathrm{C}$, Fig. $2 \mathrm{~d}$ ). In the other cases, local and foreign selection lines showed relatively similar responses, or even increased rather than decreased virulence at $32^{\circ} \mathrm{C}$ relative to the ancestor (strain 51 evolved at $32^{\circ} \mathrm{C}$; Fig. $2 \mathrm{~d}$ ). In other words, there was no clear general trend in the relationship between direct responses to selection in one temperature environment and correlated responses to selection in the other.

Vertical transmission rate. Realised rates of vertical transmission are a function of infection persistence and host replication rate ( $\approx$ infection prevalence $\mathrm{x}$ host density). Differences in

290 vertical transmission between evolved and ancestral lines varied significantly with assay temperature (assay temperature $\mathrm{x}$ selection temperature: $\mathrm{F}_{1,15}=68.98, \mathrm{p}<0.0001$; Table S2). At $32^{\circ} \mathrm{C}$, there was a clear positive direct response to selection across all strain backgrounds (Fig. 2f): Lines selected at this temperature showed up to twice as high vertical transmission rates than ancestral lines or lines from the $26^{\circ} \mathrm{C}$ selection treatment. At $26^{\circ} \mathrm{C}$, patterns varied 295 with strain genetic background (assay temperature $\mathrm{x}$ selection temperature $\mathrm{x}$ strain background: $\mathrm{F}_{6}, 15=5.35, \mathrm{p}=0.0039$; Table $\mathrm{S} 2$ ), but in no case, selection at $26^{\circ} \mathrm{C}$ seemed to have consistently improved vertical transmission over that of ancestral backgrounds (Fig. 2e). 
bioRxiv preprint doi: https://doi.org/10.1101/2020.01.23.917773; this version posted January $24,2020$. The copyright holder for this preprint (which was not certified by peer review) is the author/funder, who has granted bioRxiv a license to display the preprint in perpetuity. It is made available under aCC-BY-NC-ND 4.0 International license.

If anything, certain lines selected at $32^{\circ} \mathrm{C}$ showed the highest transmission rates, meaning that correlated responses to selection at $32^{\circ} \mathrm{C}$ were higher than the direct responses to selection at

\section{Trait correlations}

Multiple regression analysis. Analysis of the relationships between trait changes (Table S3) showed that improvement in vertical transmission at $26^{\circ} \mathrm{C}$ (be it through direct or correlated responses to selection) was primarily associated with a decrease in virulence $\left(\mathrm{F}_{1,20}=10.58, \mathrm{p}\right.$ $=0.0040$; Fig. 3$)$. At $32^{\circ} \mathrm{C}$, both increases in infection persistence $\left(\mathrm{F}_{1,20}=9.96, \mathrm{p}=0.0050\right)$ and decreases in virulence $\left(\mathrm{F}_{1,20}=4.42, \mathrm{p}=0.0483\right)$ made significant contributions to improved vertical transmission. However, the path through persistence change produced a stronger signal than that through virulence change (Fig. 3).

310 Trade-off analysis. We found little evidence for trade-offs involved in temperature-specific adaptation. If anything, the correlation between vertical transmission rate at $26^{\circ} \mathrm{C}$ and $32^{\circ} \mathrm{C}$ was positive, rather than negative (all monoclonal lines combined, with two outliers removed: $\mathrm{r}=0.19 ; \mathrm{n}=79, \mathrm{p}=0.0953)$. Although this correlation was only weakly positive, the covariance analysis (Table S4) revealed significant effects of strain genetic background $\left(\mathrm{F}_{3}, 15\right.$

$315=189, \mathrm{p}<0.0001)$, meaning that some genetic backgrounds have higher vertical transmission rates than others, at both 26 and $32^{\circ} \mathrm{C}$. We also detected a significant effect of selection treatment $\left(\mathrm{F}_{2}, 15=213.8, \mathrm{p}<0.0001\right)$ : Namely, several selection lines selected at $32^{\circ} \mathrm{C}$ extended the trait range of the ancestral lines (grey circle in Fig. 4) and showed highest vertical transmission rates at both 26 and $32^{\circ} \mathrm{C}$ (points in top right corner in Fig. 4). This was

320 the consequence of positive direct and correlated responses to selection at $32^{\circ} \mathrm{C}$ for these lines (see also Fig. 2e, f). 
bioRxiv preprint doi: https://doi.org/10.1101/2020.01.23.917773; this version posted January $24,2020$. The copyright holder for this preprint (which was not certified by peer review) is the author/funder, who has granted bioRxiv a license to display the preprint in perpetuity. It is made available under aCC-BY-NC-ND 4.0 International license.

\section{Discussion}

This study investigated how a host-symbiont system with obligate vertical transmission adapts to environmental stress. Because strict vertical transmission links host and symbiont fitness, we had hypothesised that adaptation to heat stress in our experimental ParameciumCaedibacter system may involve the evolution of lower virulence or even benevolence, similar to symbiont-mediated heat-stress protection in aphids (Russell and Moran 2006; Douglas 1998). We found clear evidence for improved vertical transmission rates in longterm lines evolving under temperature stress $\left(32^{\circ} \mathrm{C}\right)$. There also was a general, temperatureindependent trend towards lower virulence, but in no case infection with Caedibacter became beneficial to the host.

\section{EVOLUTION OF INCREASED INFECTION PERSISTENCE AND VERTICAL}

\section{TRANSMISSION}

Previous work had demonstrated that Caedibacter is less heat-stress tolerant than its host (Dusi et al. 2014). Consistent with these results, ancestral strains and selection lines from the $26^{\circ} \mathrm{C}$ long-term treatment showed substantial reductions in infection prevalence when exposed to $32^{\circ} \mathrm{C}$ in the 48 -h adaptation assay. This decline was also observed over the course

340 of the $32^{\circ} \mathrm{C}$ long-term treatment, but infection nonetheless persisted in the majority of selection lines until the end of the experiment. These lines retained consistently higher infection prevalence and substantially higher rates of vertical transmission at this temperature in the assay.

A straightforward explanation for these observations is adaptation of Caedibacter to

345 high-temperature stress, just like it is observed in experiments with free-living bacteria (Bennett et al. 1992; Saarinen et al. 2018), where adaptation of growth rate occurs over similar time spans. Increased heat resistance may therefore allow Caedibacter to attain viable 
bioRxiv preprint doi: https://doi.org/10.1101/2020.01.23.917773; this version posted January 24,2020 . The copyright holder for this preprint (which was not certified by peer review) is the author/funder, who has granted bioRxiv a license to display the preprint in perpetuity. It is made available under aCC-BY-NC-ND 4.0 International license.

within-host densities, track the regular dilution, when host cells divide, and thereby achieve a high fidelity and rate of vertical transmission. Adaptation was highly consistent over the four strain backgrounds tested, indicating a general evolutionary potential to respond to temperature stress.

It is often assumed that local adaptation to novel environments causes negative correlated responses to selection in other environments (Kassen 2002; Nidelet and Kaltz 2007). Here, however, selection for increased vertical transmission at $32^{\circ} \mathrm{C}$ did not seem to trade off with that at $26^{\circ} \mathrm{C}$. In fact, the overall quasi-genetic correlation even tended to be positive, such that higher rates of vertical transmission at one temperature were associated with higher rates at the other (Fig. 4). The absence of fitness costs of adaptation to hightemperature stress at permissive temperatures (such as $26^{\circ} \mathrm{C}$ here) is not uncommon (Bennett and Lenski 2007; Killeen et al. 2017), and their detection perhaps requires fitness

360 measurements at the lower end of the species' specific temperature range (Killeen et al. 2017). Our analysis of the covariance between the two present temperature environments $\left(26^{\circ} \mathrm{C}, 32^{\circ} \mathrm{C}\right)$ further revealed significant contributions from the selection treatment. Namely, the lines with the highest rates of vertical transmission at both temperatures were from $32^{\circ} \mathrm{C}$ selection treatment (Fig. 4, top right corner). Again, this finding resembles results for free-

365 living bacteria, where temperature stress did not only select for an increased temperature tolerance, but also for general improvement in fitness (Bennett and Lenski 1993, 1996). Extrapolated to a (hypothetical) geographical context, our results would then suggest that infected Paramecium from the 'marginal' $32^{\circ} \mathrm{C}$ environments can invade the permissive $26^{\circ} \mathrm{C}$ 'mainland' (see also Killeen et al. 2017). Indeed, theoretical papers have highlighted the importance of selection in marginal habitats for range expansions, even though these investigations generally focus on the reverse question of how dispersal from the mainland affects adaptation at the margins (Kirkpatrick and Barton 1997; Sexton et al. 2009). 
bioRxiv preprint doi: https://doi.org/10.1101/2020.01.23.917773; this version posted January 24,2020 . The copyright holder for this preprint (which was not certified by peer review) is the author/funder, who has granted bioRxiv a license to display the preprint in perpetuity. It is made available under aCC-BY-NC-ND 4.0 International license.

\section{VIRULENCE EVOLUTION}

375 Theory predicts that virulent symbionts with exclusive vertical transmission can persist only under very limited conditions (Ewald 1987; Jones et al. 2007). One possibility is that fitness costs are compensated through protection against biotic or abiotic stress (Brownlie and Johnson 2009; Jones et al. 2011). Caedibacter infection causes constitutive over-expression of heat-shock proteins (Grosser et al. 2018), which suggested the potential for infection to even become beneficial to the host under temperature stress (e.g., Hori and Fujishima 2003). This was not the case here. In all evolved lines, infection still substantially decreased host division relative to uninfected lines.

Nonetheless, when compared to the ancestral lines, there was a general trend towards decreased virulence over all evolved lines combined. This can be explained by the protocol of our long-term experiment, where recurrent population dilution imposed a general selection pressure for increased division rate and, by extension, increased rates of vertical transmission (see Magalon et al. 2010). Indeed, our analyses show that evolutionary increases in vertical transmission were associated with decreased virulence in both selection environments.

Importantly, however, there was no clear general signal of temperature-specific virulence evolution. Instead, we found strong interactions between strain background, selection temperature and assay temperature. Thus, only lines from strain 116 seemed to have evolved specifically low virulence at $32^{\circ} \mathrm{C}$, whereas in the other three cases, changes in virulence were independent of the selection treatment, or even showed the opposite trend of increased virulence (Fig. 2e, f). These variable outcomes explain why virulence evolution made a relatively weak contribution to vertical transmission evolution at $32^{\circ} \mathrm{C}$ (Fig. 3).

General theory holds that exclusively vertically transmitted parasites cannot be maintained if transmission is imperfect or if they reduce host fitness (Lipsitch et al. 1996). This verdict likely also holds for our Caedibacter-infected populations in the $32^{\circ} \mathrm{C}$ environments. Even though revealing clear signs of adaptation, the assay showed that vertical 
transmission is not perfect in the $32^{\circ} \mathrm{C}$-adapted lines, causing the spin-off of a considerable number of uninfected cells in only $48 \mathrm{~h}$ during the short-term adaptation assay. Repeating such periods of high population growth (compared to the relatively low growth rates in the longterm selection experiment) should therefore lead to a continuous decline in infection prevalence. These uninfected 'escapees' cannot be reinfected through horizontal transmission and this explains why infection prevalences in the long-term populations did not return to $100 \%$, despite the improved rates of vertical transmission (Fig. 1b).

\section{CAVEATS AND LIMITATIONS}

Given the observed levels of virulence and incomplete vertical transmission in our assay, it is surprising that heat-adapted infected long-term lines have persisted until the end of the experiment. In fact, even if we assume improved vertical transmission at $32^{\circ} \mathrm{C}$, uninfected individuals should gradually take over the populations in 50-60 generations (as found for strain 47, Fig. 1b). It is possible that virulence is overestimated in monoculture assays and that direct interactions in competition assays reveal more accurate (i.e., lower) values. This also

415 points to a potentially important missing piece in the picture, namely the capacity of Caedibacter-infected hosts to eliminate uninfected Paramecium (Schrallhammer and Schweikert 2009). This killer trait may compensate even large costs of infection and prevent the spread of newly cured individuals. We have not measured killer activity at $32^{\circ} \mathrm{C}$, but the persistence of uninfected cells at this temperature clearly indicates that it is impaired (see also

420 Dusi et al. 2014), similar to high-temperature sensitivity of frequency distorter functions in the vertically transmitted Wolbachia bacteria (Hurst et al. 2000). Ancestral strains differ in killer activity at $26^{\circ} \mathrm{C}$ (E. Dusi, unpublished data), but these differences do not readily explain the observed variation in infection persistence in our present assays (not shown). This calls for more detailed investigations of temperature-dependent killer trait expression and its potential to evolve at $32^{\circ} \mathrm{C}$. 
In systems with strict uniparental (asexual) vertical transmission, host and symbiont genomes are locked up within the same line of descent, and interaction traits may therefore be particularly likely to evolve as "shared traits" (Restif and Koella 2003). Separation of host and parasite contributions to the observed results would require artificial infection of the parasite in 'common garden' host backgrounds by micro-injection techniques, which are currently not available for our system. To assess possible host evolution (e.g., Killeen et al. 2017), we performed additional analyses comparing growth (AUC of cumulative density) between cured evolved and cured ancestral lines. This analysis revealed no sign of adaptation of the Paramecium to the $32^{\circ} \mathrm{C}$ treatment (overall evolved vs. ancestor: $\mathrm{t} 43=0.61$, n.s.; interaction

435 strain background $\mathrm{x}$ evolved/ancestor: $\mathrm{F}_{3,7}=1.95, \mathrm{p}>0.2$ ), suggesting that increased parasite persistence and vertical transmission are best explained by parasite adaptation.

\section{IMPLICATIONS AND CONCLUSIONS}

The robustness of "nested systems", such as host-symbiont interactions, against

440 environmental variation may critically depend on how the symbionts perceive the external environment. Temperature is a factor that can reach symbionts relatively unfiltered and is known to be a limiting factor of their survival and reproduction in uni- and multicellular hosts (Hood et al. 2010; Paaijmans et al. 2010; Duncan et al. 2011, 2017). Here we demonstrate the possibility of within-host adaptation of an obligate bacterial endosymbiont to external high-

445 temperature stress, possibly by the same mechanisms as their free-living counterparts.

Knowing the potential of symbionts and parasites to evolve such adaptations may critically determine our predictions regarding their future geographic range under changing climatic conditions (Harvell et al. 2002; Lafferty 2009). We found that adaptation to the "novel" environment was largely independent of strain genetic background and cost-free with respect

450 to performance in the "original" temperature environment. Such universality may greatly facilitate the emergence and spread of newly acquired adaptations. 
Strict vertical symbiont transmission is considered a perfect prerequisite for the evolution of mutualism (Ferdy and Godelle 2005; Moran et al. 2008; Leigh 2010), in particular when the symbiont provides protection against hostile environments or natural enemies (Oliver et al. 2003). Indeed, experimental limitation of the horizontal pathway in parasites with a mixed mode of transmission has been shown to lead to evolutionary shifts towards increased vertical transmission and "benevolence" towards their hosts (Bull et al. 1991; Magalon et al. 2010; Shapiro and Turner 2018). Our study is different from these experiments. First, we used a parasite with already naturally obligate vertical transmission

460 and, second, we focused on the consequences of its adaptation to a particular environmental condition (temperature). We found little evidence for temperature-specific adaptation of virulence, and despite the evolution of increased rates of vertical transmission, there seemed to be a general limit, below which virulence could not be reduced. This may reflect a baseline level of host resources Caedibacter needs to ensure its own reproduction and successful

465 vertical transmission. Thus, just like for parasites with horizontal transmission (van Baalen and Sabelis 1995), fitness of vertically transmitted parasites may be maximised for optimal levels of virulence.

470 Acknowledgements: We thank Alison Duncan and Emanuel Fronhofer for comments and discussion. Finn Pond provided Paramecium strains. German Research Foundation (DFG priority program Host-Parasite Coevolution: BE-2299/5-1; RA- 1920/1-1) and European FP7 program IRSES (247658) provided financial support.

475 Data archiving: The database of the adaptation assay will be archived in the Dryad Digital Repository. 


\section{Literature cited}

Adiba, S., M. Huet, and O. Kaltz. 2010. Experimental evolution of local parasite maladaptation. J. Evol. Biol. 23:1195-1205.

Alizon, S., A. Hurford, N. Mideo, and M. Van Baalen. 2009. Virulence evolution and the trade-off hypothesis: History, current state of affairs and the future. J. Evol. Biol. 22:245-259.

Bell, G. 1989. A Comparative Method. Am. Nat. 133:553-571.

Bennett, A. F., and R. E. Lenski. 2007. An experimental test of evolutionary trade-offs during temperature adaptation. Proc. Natl. Acad. Sci. 104:8649-8654.

Bennett, A. F., and R. E. Lenski. 1993. Evolutionary adaptation to temperature II. Thermal niches of experimental lines of Escherichia coli. Evolution 47:1-12.

Bennett, A. F., and R. E. Lenski. 1996. Evolutionary adaptation to temperature. V. Adaptive mechanisms and correlated responses in experimental lines of Escherichia coli. Evolution 50:493-503.

Bennett, A. F., R. E. Lenski, and J. E. Mittler. 1992. Evolutionary adaptation to temperature. I. Fitness responses of Escherichia coli to changes in its thermal environment. Evolution 46:16-30.

Brown, J. K. 2003. A cost of disease resistance: paradigm or peculiarity? Trends Genet. 19:667-671.

Brownlie, J. C., and K. N. Johnson. 2009. Symbiont-mediated protection in insect hosts. Trends Microbiol 17:348-354.

495 Brucker, R. M., and S. R. Bordenstein. 2012. Speciation by symbiosis. Trends Ecol. Evol. 27:443-451.

Bull, J. J., I. J. Molineux, and W. R. Rice. 1991. Selection of benevolence in a host-parasite system. Evolution 45:875-882.

Capaul, M., and D. Ebert. 2003. Parasite-mediated selection in experimental Daphnia magna populations. Evolution 57:249-260.

500 Cayetano, L., and C. Vorburger. 2013. Genotype-by-genotype specificity remains robust to average temperature variation in an aphid/endosymbiont/parasitoid system. J Evol Biol 26:1603-1610.

Dale, C., and N. A. Moran. 2006. Molecular interactions between bacterial symbionts and their hosts. Cell 126:453-465.

Douglas, A. E. 1998. Nutritional interactions in insect-microbial symbioses: aphids and their symbiotic bacteria Buchnera. Annu. Rev. Entomol. 43:17-37. 
bioRxiv preprint doi: https://doi.org/10.1101/2020.01.23.917773; this version posted January 24,2020 . The copyright holder for this preprint (which was not certified by peer review) is the author/funder, who has granted bioRxiv a license to display the preprint in perpetuity. It is made available under aCC-BY-NC-ND 4.0 International license.

Dryl, S. 1959. Antigenic transformation in Paramecium aurelia after homologous antiserum treatment during autogamy and conjugation. J. Protozool. 6:s96.

Dunbar, H. E., A. C. Wilson, N. R. Ferguson, and N. A. Moran. 2007. Aphid thermal tolerance is governed by a point mutation in bacterial symbionts. PLoS Biol. 5:e96.

510 Duncan, A. B., E. Dusi, F. Jacob, J. Ramsayer, M. E. Hochberg, and O. Kaltz. 2017. Hot spots become cold spots: coevolution in variable temperature environments. J. Evol. Biol. 30:55-65.

Duncan, A. B., S. Fellous, and O. Kaltz. 2011. Temporal variation in temperature determines disease spread and maintenance in Paramecium microcosm populations. Proc. R. Soc. B Biol. Sci. 278:3412-3420.

515 Dunn, A. M., and J. E. Smith. 2001. Microsporidian life cycles and diversity: The relationship between virulence and transmission. Microbes Infect. 3:381-388.

Dunn, A. M., R. S. Terry, and J. E. Smith. 2001. Transovarial transmission in the microsporidia. Adv. Parasitol. 48:57-100.

Dusi, E., C. Gougat-Barbera, T. U. Berendonk, and O. Kaltz. 2015. Long-term selection experiment produces breakdown of horizontal transmissibility in parasite with mixed transmission mode. Evolution 69:1069-1076.

Dusi, E., S. Krenek, M. Schrallhammer, R. Sachse, G. Rauch, O. Kaltz, and T. U. Berendonk. 2014. Vertically transmitted symbiont reduces host fitness along temperature gradient. J. Evol. Biol. $27: 796-800$.

525 Ebert, D. 2013. The epidemiology and evolution of symbionts with mixed-mode transmission. Ann. Rev. Ecol. Evol. Syst. 44:623-643.

Ewald, P. W. 1987. Transmission modes and the evolution of the parasitism-mutualism continuum. Ann. N. Y. Acad. Sci. 503:295-306.

Feldhaar, H. 2011. Bacterial symbionts as mediators of ecologically important traits of insect hosts. Ecol. Entomol. 36:533-543.

Fellous, S., and L. Salvaudon. 2009. How can your parasites become your allies? Trends Parasitol. $25: 62-66$. 
bioRxiv preprint doi: https://doi.org/10.1101/2020.01.23.917773; this version posted January 24,2020 . The copyright holder for this preprint (which was not certified by peer review) is the author/funder, who has granted bioRxiv a license to display the preprint in perpetuity. It is made available under aCC-BY-NC-ND 4.0 International license.

Ferdy, J., and B. Godelle. 2005. Diversification of transmission modes and the evolution of mutualism. Am. Nat. 166:613-627.

Fine, P. E. M. 1975. Vectors and vertical transmission: an epidemiologic perspective. Ann. N. Y. Acad. Sci. 266:173-194.

Gotoh, T., H. Noda, and S. Ito. 2007. Cardinium symbionts cause cytoplasmic incompatibility in spider mites. Heredity 98:13-20.

Grosser, K., P. Ramasamy, A. D. Amirabad, M. H. Schulz, G. Gasparoni, M. Simon, and M. Schrallhammer. 2018. More than the "killer Trait": Infection with the Bacterial Endosymbiont Caedibacter taeniospiralis Causes Transcriptomic Modulation in Paramecium Host. Genome Biol. Evol. 10:646-656.

Haine, E. R. 2008. Symbiont-mediated protection. Proc. R. Soc. B Biol. Sci. 275:353-361.

Harvell, C. D., C. E. Mitchell, J. R. Ward, S. Altizer, A. P. Dobson, R. S. Ostfeld, and M. D. Samuel. 2002. Climate warming and disease risks for terrestrial and marine biota. Science 296:21582162.

Hatcher, M. J., J. C. Hogg, and A. M. Dunn. 2005. Local adaptation and enhanced virulence of Nosema granulosis artificially introduced into novel populations of its crustacean host, Gammarus duebeni. Int. J. Parasitol. 35:265-274.

550 He, J. S., X. Wang, D. F. Flynn, L. Wang, B. Schmid, and J. Fang. 2009. Taxonomic, phylogenetic, and environmental trade-offs between leaf productivity and persistence. Ecology 90:2779-2791.

Hood, M. E., J. I. Mena-Alí, A. K. Gibson, B. Oxelman, T. Giraud, R. Yockteng, M. T. K. Arroyo, F. Conti, A. B. Pedersen, P. Gladieux, and J. Antonovics. 2010. Distribution of the anther-smut pathogen Microbotryum on species of the Caryophyllaceae. New Phytol. 187:217-229.

555 Hori, M., and M. Fujishima. 2003. The endosymbiotic bacterium Holospora obtusa enhances heat-shock gene expression of the host Paramecium caudatum. J. Eukaryot. Microbiol. 50:293-298.

Hurst, G. D., A. P. Johnson, J. H. Schulenburg, and Y. Fuyama. 2000. Male-killing Wolbachia in Drosophila: a temperature-sensitive trait with a threshold bacterial density. Genetics 156:699709.

560 Jaenike, J. 2015. Heritable symbionts contribute to host plant adaptation. Funct. Ecol. 29:1371-1372. 
Jones, E. O., A. White, and M. Boots. 2007. Interference and the persistence of vertically transmitted parasites. J. Theor. Biol. 246:10-17.

Jones, E. O., A. White, and M. Boots. 2011. The evolution of host protection by vertically transmitted parasites. Proc. R. Soc. B Biol. Sci. 278:863-870.

565 Kassen, R. 2002. The experimental evolution of specialists, generalists and the maintenance of diversity. J. Evol. Biol. 15:173-190.

Kelly, A., M. J. Hatcher, and A. M. Dunn. 2003. The impact of a vertically transmitted microsporidian, Nosema granulosis on the fitness of its Gammarus duebeni host under stressful environmental conditions. Parasitology 126:119-124.

570 Killeen, J., C. Gougat-Barbera, S. Krenek, and O. Kaltz. 2017. Evolutionary rescue and local adaptation under different rates of temperature increase: a combined analysis of changes in phenotype expression and genotype frequency in Paramecium microcosms. Mol. Ecol. 26:1734-1746.

Kirkpatrick, M., and N. H. Barton. 1997. Evolution of a species’ range. Am. Nat. 150:1-23.

Krenek, S., T. U. Berendonk, and T. Petzoldt. 2011. Thermal performance curves of Paramecium caudatum: a model selection approach. Eur. J. Protistol. 47:124-137.

Krenek, S., T. Petzoldt, and T. U. Berendonk. 2012. Coping with temperature at the warm edge--patterns of thermal adaptation in the microbial eukaryote Paramecium caudatum. PLoS ONE 7:e30598.

Lafferty, K. D. 2009. The ecology of climate change and infectious diseases. Ecology 90:888-900.

Leigh, E. G. 2010. The evolution of mutualism. J. Evol. Biol. 23:2507-2528.

580 Leung, T. L. F., and R. Poulin. 2008. Parasitism, commensalism, and mutualism: Exploring the many shades of symbioses. Vie Milieu 58:107-115.

Lipsitch, M., S. Siller, and M. A. Nowak. 1996. The evolution of virulence in pathogens with vertical and horizontal transmission. Evolution 50:1729- 1741.

Magalon, H., T. Nidelet, G. Martin, and O. Kaltz. 2010. Host growth conditions influence experimental evolution of life history and virulence of a parasite with vertical and horizontal transmission. Evolution 64:2126-2138.

Mahmud, M. A., J. E. Bradley, and A. D. C. MacColl. 2017. Abiotic environmental variation drives virulence evolution in a fish host-parasite geographic mosaic. Funct. Ecol. 31:2138-2146. 
bioRxiv preprint doi: https://doi.org/10.1101/2020.01.23.917773; this version posted January 24,2020 . The copyright holder for this preprint (which was not certified by peer review) is the author/funder, who has granted bioRxiv a license to display the preprint in perpetuity. It is made available under aCC-BY-NC-ND 4.0 International license.

Mangin, K. L., M. Lipsitch, and D. Ebert. 1995. Virulence and transmission modes of two microsporidia in Daphnia magna. Parasitology 111:133-142.

Michalakis, Y., I. Olivieri, F. Renaud, and M. Raymond. 1992. Pleiotropic action of parasites: How to be good for the host. Trends Ecol. Evol. 7:59-62.

Moran, N. A., J. P. McCutcheon, and A. Nakabachi. 2008. Genomics and evolution of heritable bacterial symbionts. Annu. Rev. Genet. 42:165-190.

595 Mouton, L., F. Dedeine, H. Henri, M. Boulétreau, N. Profizi, and F. Vavre. 2004. Virulence, multiple infections and regulation of symbiotic population in the Wolbachia-Asobara tabida symbiosis. Genetics 168:181-189.

Mouton, L., H. Henri, M. Bouletreau, and F. Vavre. 2003. Strain-specific regulation of intracellular Wolbachia density in multiply infected insects. Mol. Ecol. 12:3459-3465.

600 Mouton, L., H. Henri, D. Charif, M. Boulétreau, and F. Vavre. 2007. Interaction between host genotype and environmental conditions affects bacterial density in Wolbachia symbiosis. Biol. Lett. $3: 210-213$

Nidelet, T., and O. Kaltz. 2007. Direct and correlated responses to selection in a host-parasite system: testing for the emergence of genotype specificity. Evolution 61:1803-11.

605 Oliver, K. M., N. A. Moran, and M. S. Hunter. 2005. Variation in resistance to parasitism in aphids is due to symbionts not host genotype. Proc. Natl. Acad. Sci. 102:12795-12800.

Oliver, K. M., J. A. Russell, N. A. Moran, and M. S. Hunter. 2003. Facultative bacterial symbionts in aphids confer resistance to parasitic wasps. Proc Natl Acad Sci U A 100:1803-1807.

Paaijmans, K. P., S. Blanford, A. S. Bell, J. I. Blanford, A. F. Read, and M. B. Thomas. 2010. Influence of climate on malaria transmission depends on daily temperature variation. Proc Natl Acad Sci U A 107:15135-15139.

Pariaud, B., F. Berg, F. Bosch, S. J. Powers, O. Kaltz, and C. Lannou. 2013. Shared influence of pathogen and host genetics on a trade-off between latent period and spore production capacity in the wheat pathogen, Puccinia triticina. Evol. Appl. 6:303-312.

615 Preer, J. R., and L. B. Preer. 1982. Revival of names of Protozoan endosymbionts and proposal of Holospora caryohila nom. nov. Int. J. Syst. Bacteriol. 32:140-141. 
bioRxiv preprint doi: https://doi.org/10.1101/2020.01.23.917773; this version posted January 24,2020 . The copyright holder for this preprint (which was not certified by peer review) is the author/funder, who has granted bioRxiv a license to display the preprint in perpetuity. It is made available under aCC-BY-NC-ND 4.0 International license.

Preer, J. R., L. B. Preer, and A. Jurand. 1974. Kappa and Other Endosymbionts in Paramecium aurelia. Bacteriol. Rev. 38:113-163.

Restif, O., and O. Kaltz. 2006. Condition-dependent virulence in a horizontally and vertically 620 transmitted bacterial parasite. OIKOS 114:148-158.

Restif, O., and J. C. Koella. 2003. Shared control of epidemiological traits in a coevolutionary model of host-parasite interactions. Am Nat 161:827-836.

Rouchet, R., and C. Vorburger. 2014. Experimental evolution of parasitoid infectivity on symbiontprotected hosts leads to the emergence of genotype specificity. Evolution 68:1607-1616.

625 Russell, J. A., and N. A. Moran. 2006. Costs and benefits of symbiont infection in aphids: Variation among symbionts and across temperatures. Proc. R. Soc. B Biol. Sci. 273:603-610.

Saarinen, K., J. Laakso, L. Lindström, and T. Ketola. 2018. Adaptation to fluctuations in temperature by nine species of bacteria. Ecol. Evol. 8:2901-2910.

Sachs, J. L., R. G. Skophammer, and J. U. Regus. 2011. Evolutionary transitions in bacterial symbiosis. Proc. Natl. Acad. Sci. USA 108 Suppl:10800-10807.

SAS Institute. 2017. JMP®, Version 13. SAS Institute Inc., Cary, N.C.

Schrallhammer, M., and M. Schweikert. 2009. The killer effect of Paramecium and its causative agents. Pp. 227-246 in Endosymbionts in Paramecium. Springer, Berlin.

Sexton, J. P., P. J. McIntyre, A. L. Angert, and K. J. Rice. 2009. Evolution and ecology of species range limits. Annu. Rev. Ecol. Evol. Syst. 40:415-436.

Shapiro, J. W., and P. E. Turner. 2018. Evolution of mutualism from parasitism in experimental virus populations. Evolution 72:707-712.

Sonneborn, T. M. 1943. Gene and Cytoplasm: I. The determination and inheritance of the killer character in variety 4 of Paramecium aurelia. Proc. Natl. Acad. Sci. U. S. A. 29:329-338.

640 Sorensen, J. G., T. N. Kristensen, and V. Loeschcke. 2003. The evolutionary and ecological role of heat shock proteins. Ecol. Lett. 6:1025-1037.

Thomas, M. B., and S. Blanford. 2003. Thermal biology in insect-parasite interactions. Trends Ecol. Evol. 18:344-350. 
Thompson, J. N., and C. C. Fernandez. 2006. Temporal dynamics of antagonism and mutualism in a geographically variable plant-insect interaction. Ecology 87:103-112.

Thrall, P. H., M. E. Hochberg, J. J. Burdon, and J. D. Bever. 2007. Coevolution of symbiotic mutualists and parasites in a community context. Trends Ecol Evol 22:120-126.

Vale, P. F., A. J. Wilson, A. Best, M. Boots, and T. J. Little. 2011. Epidemiological, evolutionary, and coevolutionary implications of context-dependent parasitism. Am. Nat. 177:510-521.

van Baalen, M., and M. W. Sabelis. 1995. Dynamics of multiple infection and the evolution of virulence. Am. Nat. 146:881-910.

Werren, J. H. 1997. Biology of Wolbachia. Annu. Rev. Entomol. 42:587-609.

Wolinska, J., and K. King. 2009. Environment can alter selection in host-parasite interactions. Trends Parasitol. 25:236-244. 
bioRxiv preprint doi: https://doi.org/10.1101/2020.01.23.917773; this version posted January $24,2020$. The copyright holder for this preprint (which was not certified by peer review) is the author/funder, who has granted bioRxiv a license to display the preprint in perpetuity. It is made available under aCC-BY-NC-ND 4.0 International license.

\section{Figure captions}

Fig. 1. Population density (a) and infection prevalence (b) in individual long-term selection lines from each of five strain genetic backgrounds $(47, \mathrm{~A} 30,51,116,298)$ propagated at $26^{\circ} \mathrm{C}$ (blue symbols) or $32^{\circ} \mathrm{C}$ (red symbols), over the course of 52 weeks $(\approx 150$ host generations). Densities were taken in 2-month intervals. Only pooled prevalence data (combined over selection lines from the same strain and treatment) were available for the first half of the experiment, and trajectories are shown as stippled to indicate uncertainty of divergence of selection lines (i.e., when pooled prevalences were $<1$ ). After week 30, prevalences are shown for individual long-term lines.

Fig. 2. Infection prevalence $(a, b)$, virulence $(c, d)$ and vertical transmission rate $(e, f)$ in the adaptation assay, carried out at $26^{\circ} \mathrm{C}$ and $32^{\circ} \mathrm{C}$ assay temperature. Each panel shows the mean ( $\pm \mathrm{SE}$ ) for selection lines from $26^{\circ} \mathrm{C}$ (blue symbols) or $32^{\circ} \mathrm{C}$ (red symbols) selection treatments as well as the corresponding ancestral lines (open symbols), from each of four genetic strain backgrounds. Asterisks indicate significant differences $(\mathrm{p}<0.05)$ between $26^{\circ} \mathrm{C}$ and $32^{\circ} \mathrm{C}$ selection treatments, as revealed by post-hoc contrasts.

675

Fig. 3. Relationships between trait changes, as revealed by multiple regression, using change in vertical transmission rate as response variable and changes in infection persistence and virulence as explanatory variables. Trait change was calculated as the difference between evolved and ancestral lines. Separate analyses were performed for $26^{\circ} \mathrm{C}$ and $32^{\circ} \mathrm{C}$ assay temperatures, respectively. Values for unidirectional arrows represent standardised beta regression coefficients; values for bidirectional arrows are correlation coefficients. For convenience, we denote the direction of change for each trait (increase or decrease relative to ancestor); the coefficients indicate the relationship between these increases / decreases. 
Fig. 4. Relationship between vertical transmission rate at $26^{\circ} \mathrm{C}$ and at $32^{\circ} \mathrm{C}$ assay temperature,

685 shown for selection lines evolved at $32^{\circ} \mathrm{C}$ (red) or $26^{\circ} \mathrm{C}$ (blue) and for ancestral lines (grey).

Each point represents the mean $( \pm \mathrm{SE})$ for an individual selection line. The grey circle

illustrates the ancestral trait range. Different symbols refer to four different strain

backgrounds $(116,298,51, \mathrm{~A} 30)$; the origin of the temperature selection treatment $\left(26^{\circ} \mathrm{C}\right.$ or

$32^{\circ} \mathrm{C}$ ) is shown within each symbol.

690 
bioRxiv preprint doi: https://doi.org/10.1101/2020.01.23.917773; this version posted January 24, 2020. The copyright holder for this preprint (which was not certified by peer review) is the author/funder, who has granted bioRxiv a license to display the preprint in perpetuity. It is made available under aCC-BY-NC-ND 4.0 International license.

Fig. 1

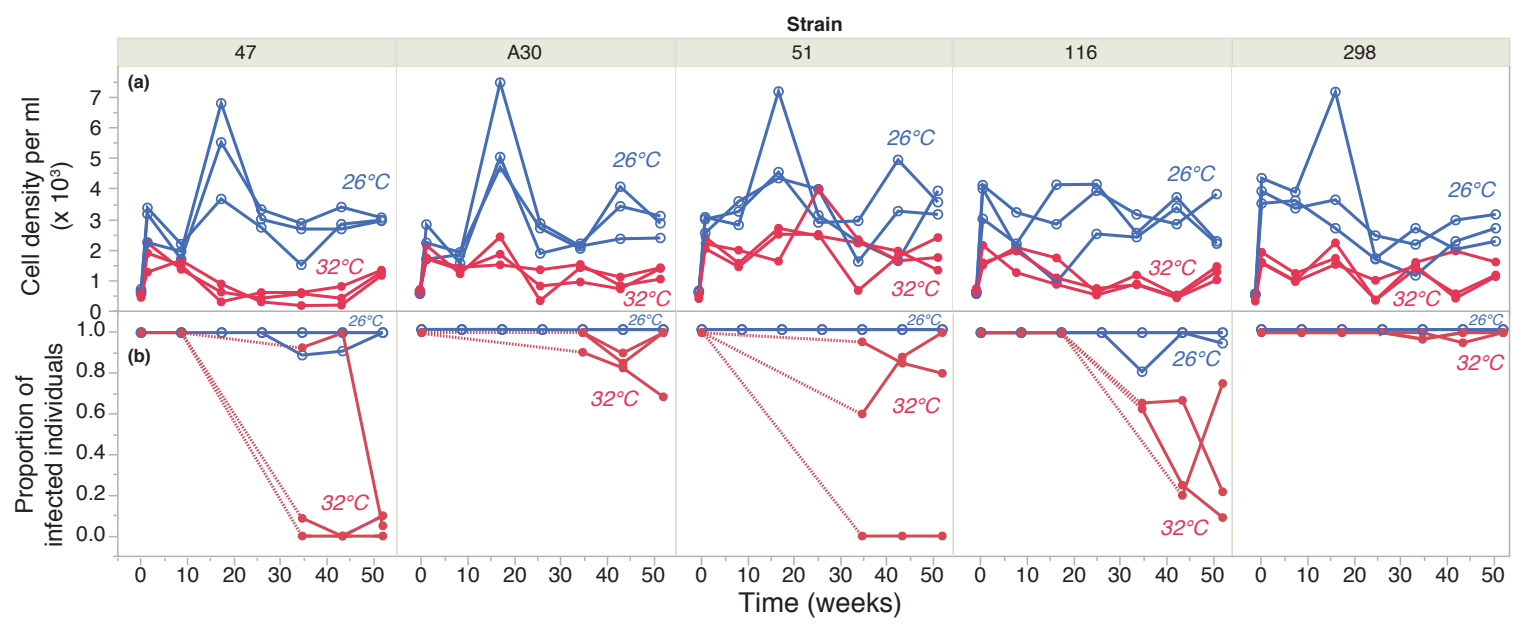


bioRxiv preprint doi: https://doi.org/10.1101/2020.01.23.917773; this version posted January 24, 2020. The copyright holder for this preprint (which was not certified by peer review) is the author/funder, who has granted bioRxiv a license to display the preprint in perpetuity. It is made available under aCC-BY-NC-ND 4.0 International license.

Fig. 2

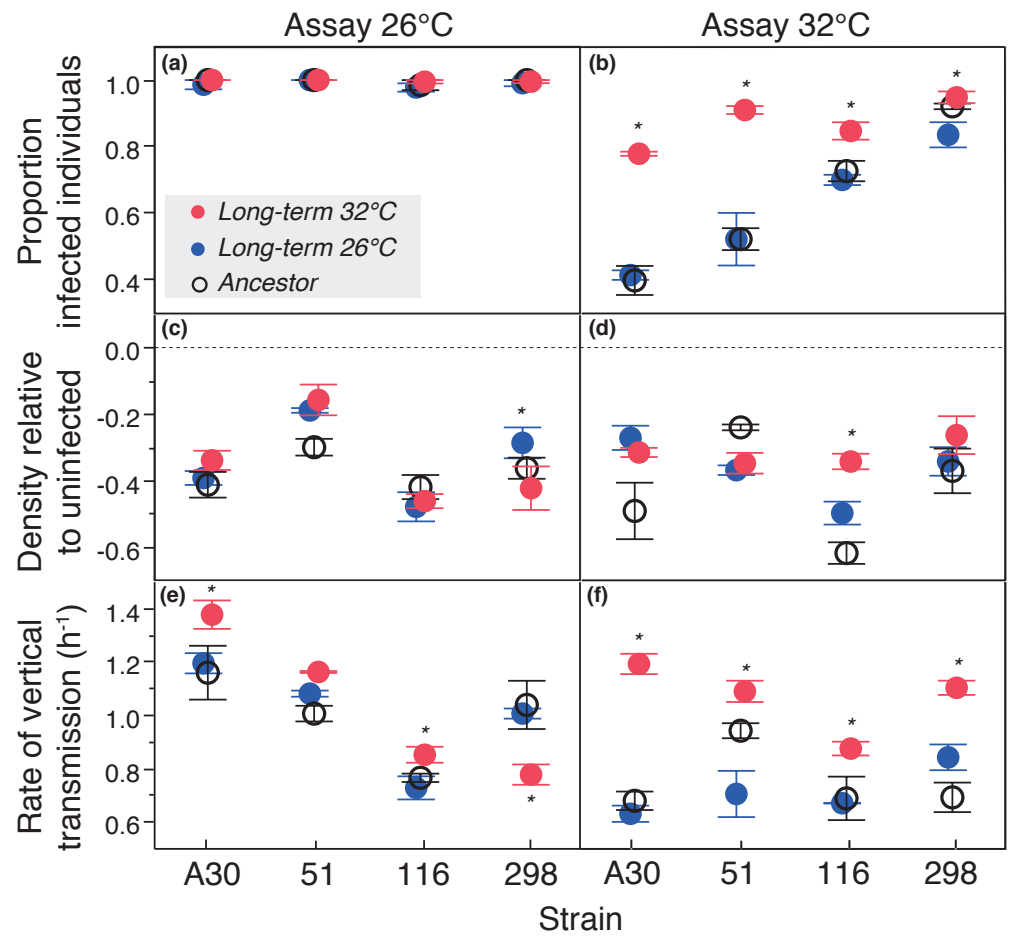


bioRxiv preprint doi: https://doi.org/10.1101/2020.01.23.917773; this version posted January 24, 2020. The copyright holder for this preprint (which was not certified by peer review) is the author/funder, who has granted bioRxiv a license to display the preprint in perpetuity. It is made available under aCC-BY-NC-ND 4.0 International license.

Fig. 3

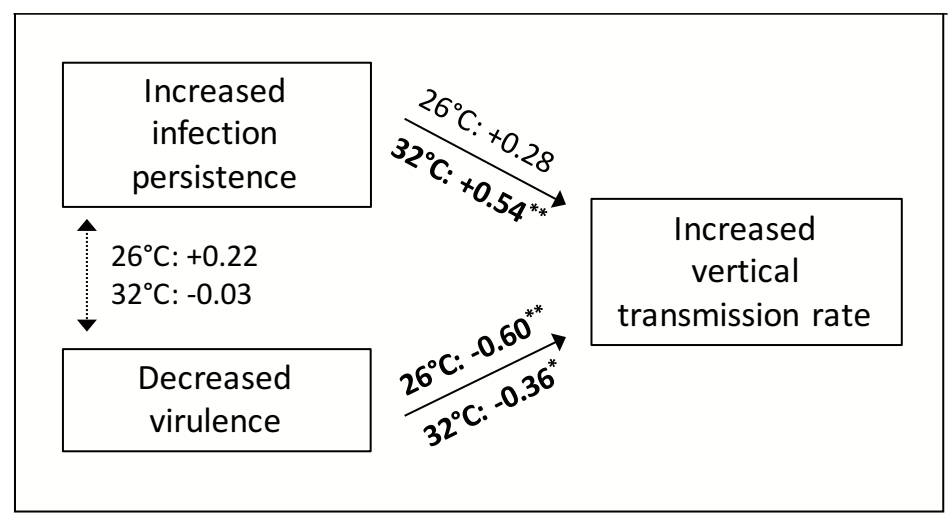


bioRxiv preprint doi: https://doi.org/10.1101/2020.01.23.917773; this version posted January 24, 2020. The copyright holder for this preprint (which was not certified by peer review) is the author/funder, who has granted bioRxiv a license to display the preprint in perpetuity. It is made available under aCC-BY-NC-ND 4.0 International license.

Fig. 4

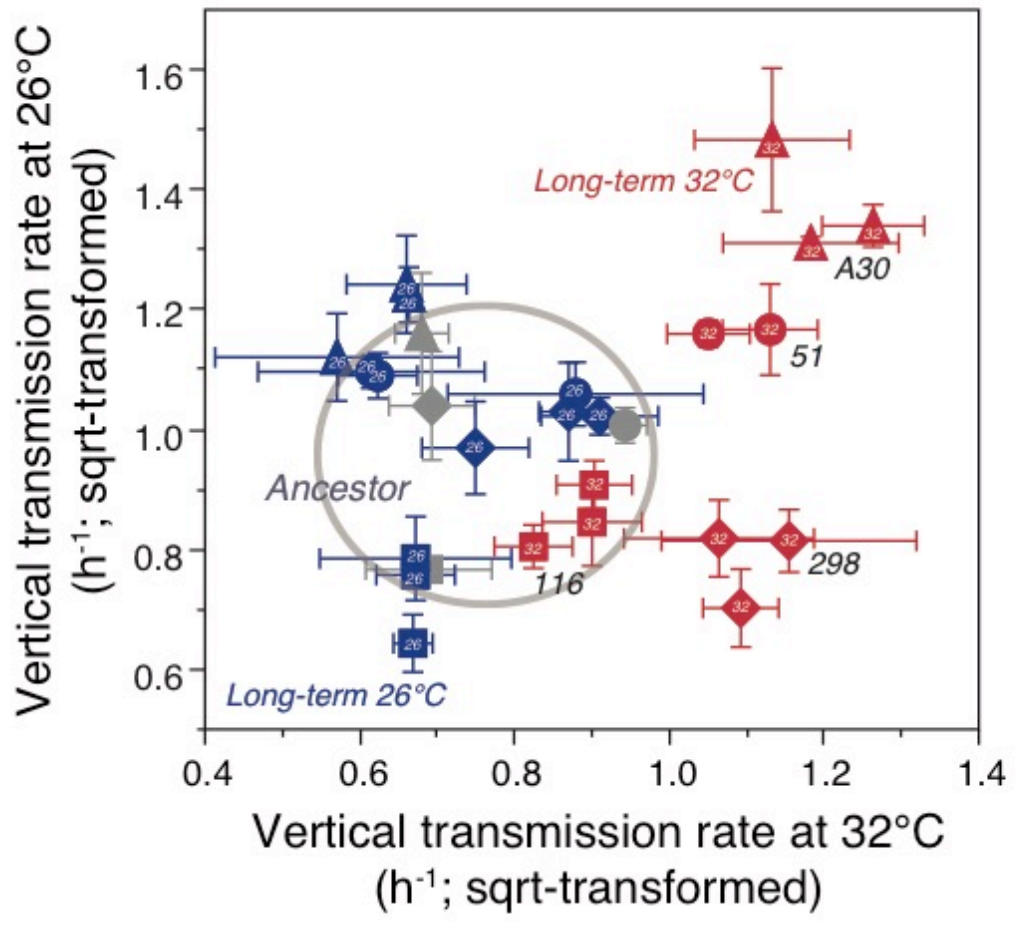

